\title{
Microcurrent application as analgesic treatment in venous ulcers: a pilot study
}

\author{
Raciele Ivandra Guarda Korelo ${ }^{1}$ \\ Silvia Valderramas ${ }^{2}$ \\ Bruno Ternoski ${ }^{3}$ \\ Danilo Sanches Medeiros ${ }^{3}$ \\ Letícia Fernandes Andres ${ }^{3}$ \\ Sandra Mara Meireles Adolph ${ }^{4}$
}

\begin{abstract}
This study aimed to evaluate the effect of microcurrent electrical stimulation on pain and area of venous ulcers. In a pilot study for a single-blind controlled clinical trial, carried out at an outpatient clinic during four weeks, 14 subjects with venous ulcers (mean age $62 \pm 9$ years) were divided in two groups: microcurrent $(n=8)$ and control group $(n=6)$. Pain (by Visual Analogue Scale) and the ulcer area were measured by planimetry. There was a significant difference between the two groups with respect to pain (microcurrent group from 8.5 (6.5$9.75)$ to 3.5 (1-4.75) and control group from $7.5(5.75-10)$ to $8.5(5.5-10), p<0.01)$. Non-significant changes were found with respect to ulcer area (planimetry by graph paper, $p=0.41$ and by Image ${ }^{\circledR}, p=0.41$ ). In conclusion, the application of microcurrent improves the pain of patients with venous ulcers (ClinicalTrials.gov: NCT01372020).

Descriptors: Varicose Ulcer; Wound Healing; Electrical Stimulation.
\end{abstract}

\footnotetext{
${ }^{1}$ Doctoral student, Universidade Federal do Paraná, Brazil. Professor, Universidade Federal do Paraná, Brazil.

2 PhD, Professor, Faculdade Dom Bosco, Brazil. Professor, Faculdade Evangélica do Paraná, Brazil.

3 Physical Therapist, Faculdade Dom Bosco, Brazil.

${ }^{4}$ PhD, Professor, Faculdade Dom Bosco, Brazil.
} 


\title{
Aplicação da microcorrente como recurso para tratamento de úlceras venosas: um estudo piloto
}

O objetivo neste estudo foi avaliar o efeito da estimulação elétrica, por microcorrente, sobre a dor e a área de superfície de úlceras venosas. Em estudo-piloto para um ensaio clínico controlado simples-cego, realizado em uma clínica durante 4 semanas, dividiramse 14 indivíduos (62 99 anos de idade) em dois grupos: grupo microcorrente $(n=8)$ e grupo-controle $(n=6)$. Avaliaram-se a dor (por meio da Escala Visual Analógica) e a área de superfície da úlcera por meio da Planimetria. Houve diferença significativa entre os dois grupos em relação à dor (grupo de microcorrente de $8,5(6,5-9,75)$ para 3,5 (1$4,75)$ e grupo-controle de $7,5(5,75-10)$ para $8,5(5,5-10), p<0,01)$ ). Não se verificou diferença significativa relacionada à área de superfície da úlcera (Planimetria com papel vegetal, $p=0,41$ e pelo software Image ${ }^{\circledR}, p=0,41$ ). Conclui-se que a aplicação de microcorrente melhora o quadro álgico de indivíduos com úlceras venosas. Registro ClinicalTrials.gov: NCT01372020.

Descritores: Úlcera Varicosa; Cicatrização de Feridas; Estimulação Elétrica.

\section{La aplicación de microcorriente como tratamiento en las úlceras venosas: un estudio piloto}

\begin{abstract}
Este estudio objetivó evaluar el efecto de la estimulación eléctrica por microcorriente sobre el dolor y el área de superficie de úlceras venosas. En un estudio piloto para un ensayo clínico controlado simple ciego, realizado en una clínica durante 4 semanas, se dividieron 14 individuos ( $62 \pm 9$ años de edad) en dos grupos: grupo microcorriente $(n=8)$ y grupo control $(n=6)$. Se evaluaron el dolor (por medio de la Escala Visual Analógica) y el área de superficie de la úlcera por medio de la Planimetría. Hubo diferencia significativa entre los dos grupos con relación al dolor (grupo de microcorriente de $8,5(6,5-9,75)$ para 3,5 $(1-4,75)$ y grupo control de $7,5(5,75-10)$ para $8,5(5,5-10), p<0,01))$. No se verificó una diferencia significativa relacionada al área de superficie de la úlcera (Planimetría con papel vegetal, $p=0,41$ y por el software Image $]^{\circledR}, p=0,41$ ). Se concluye que la aplicación de microcorriente mejora el cuadro álgico de individuos con úlceras venosas. Registro ClinicalTrials.gov: NCT01372020.
\end{abstract}

Descriptores: Úlcera Varicosa; Cicatrización de Heridas; Estimulación Eléctrica.

\section{Introduction}

Venous ulcers are characterized by a loss of skin continuity, cutaneous hyperpigmentation, edema, healing deficit, pain and lipodermatosclerosis ${ }^{(1)}$. Their genesis has not been clarified yet, but the scientific community suggests that the best accepted factor is venous reflux ${ }^{(2)}$. Their evolution is slow, their duration undefined and relapses can extend for months or years. They affect between 0.06 and $3.6 \%$ of the adult population and their prevalence increases with the age range. Venous ulcers negatively affect social and economic issues, producing pain and decreasing patients' quality of life during the tissue restoration

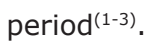

In systematic reviews, pain is mentioned as the first and most frequent experience related to venous ulcers $^{(4-5)}$. It is caused by tissue aggression, ischemia, hypoxia, inflammation, infection or adherences to the wound bed ${ }^{(3)}$. Pain is a constant symptom, but its appearance and intensity vary during the day ${ }^{(6)}$. This symptom causes delayed healing and hampers daily activities, mainly because of reduced mobility and sleep disorders, besides psychological and emotional 
alterations like decreased trust to accomplish daily activities. It also affect patients' well-being and their maintenance of social and leisure activities, manifested through a feeling of isolation, identity loss, mood swings and decreased quality of life ${ }^{(5-8)}$. Therefore, adequate pain control enhances treatment adherence, mobility and positively influences quality of life ${ }^{(9-10)}$. Pain can be mitigated through pharmacological (analgesic and anti-inflammatory drugs) and non-pharmacological measures like debridement (removes bacteria that may be causing pain)(11), phytotherapeutic drugs, rest, limb elevation, massage and dressings ${ }^{(12)}$.

Chronic venous ulcer treatment can be accomplished through a set of measures, among which scientific evidence appoints compressive therapies as the first treatment option ${ }^{(13)}$; associated with simple (Vaseline, mineral oil, silver sulphadiazine and sugar) or more complex dressings (hydrogel, transparent film, activated carbon, Unna boot, among others), which did not reveal mutual differences in terms of treatment efficacy in a systematic review ${ }^{(14)}$. Other co-adjuvant measures can be used, as research has been inconclusive so far, including Complex Physical Therapy (consists in a combination of manual lympathic drainage, elastic compression, muscular lymphokinetic exercises and skin care)(2), degravitation of the affected limb, non-topical pharmacological measures like systemic antibiotics therapy for infection control, surgical techniques that decrease relapses and, more recently, electrothermotherapy(3,15-16).

Electro-thermotherapeutic resources started to be used in wound healing after the discovery of the endogenous production of electric fields in tissue injuries, resulting from the sodium channels in the membrane that permit internal sodium diffusion(17). Based on these concepts, studies show that MENS - Microcurrent Electric Neuromuscular Stimulation is conceived as a useful option to initiate, perpetuate and sustain the countless electrical and chemical events that occur in the healing process, besides enhancing local circulation and relieving pain ${ }^{(18-19)}$.

Nowadays, interest in the use of low-intensity current use like MENS is increasing, as its effects take place at the cell level (normalizing bioelectricity), and their application is sub-sensory (not associated with unpleasant feelings like in other currents, i.e. they are painless), besides the absence of collateral effect, low cost and easy application ${ }^{(17)}$.

The physiological effects include: re-establishment of tissue bio-electricity with increased transportation through the plasma membrane, increased synthesis of adenosine triphosphate and transportation of amino acids, accelerated protein synthesis and stimulation of conjunctive tissue growth(20-22). Therefore, the microcurrent is considered an alternative for wound treatment with reparation difficulties, favoring devitalized tissue like pressure, diabetic, stasis and arterial ulcers(17). Despite this assertion, the role of microcurrent as a venous ulcer treatment alternative has not been defined yet. Also, it is questioned whether the use of such low amplitudes benefits wound healing.

This study is also justified by the fact that the microcurrent acts on the pain, because the ulcers cause important functional changes, deriving from the painful condition, mainly in people of productive age. This fact may distance them from work, aggravate their socioeconomic situation and even hamper their treatment access due to locomotion difficulties.

In view of the above, this research is developed to assess the effect of microcurrent electric neuromuscular stimulation on pain and the venous ulcer area.

\section{Methods}

This pilot study for a controlled clinical trial was accomplished at a Physiotherapy teaching clinic between February and November 2010. Approval for the study was obtained from the institution's Research Ethics Committee (No. 0002.0.301.000-10) and all subjects involved signed the Informed Consent Term.

Male and female individuals were selected, over 50 years of age, with a clinical diagnosis of venous ulcer in the lower limbs, sedentary, and under clinical treatment only based on simple dressings (general ulcer hygiene measures using saline solution and occlusive dressings using gauze) and lower limb degravitation.

Individuals with by-pass, diabetes, uncontrolled systemic arterial hypertension, osteomyelitis and pains of unknown origin were excluded, as well as people who did not walk or used compressive methods, oral or topical drugs of direct action in the healing process or analgesics during the intervention period were excluded.

All patients submitted to an evaluation for demographic, socioeconomic and clinical data collection by the same evaluator.

Pain was assessed at two times (before the intervention and four weeks later) with the help of the Visual Analogue Scale (VAS) and the ulcer area was measured using classical planimetry(23) and digital images $^{(24)}$. 


\section{Planimetry}

To apply planimetry, a vegetal paper with $70 \%$ alcohol was placed on the ulcer and fixed to contour the ulcer border, using a pen. After marking the ulcer on the vegetal paper, two methods were employed to determine the total ulcer area: 1 ) superposition of the vegetal paper on millimeter paper(23), and counting of the number of squares in the ulcer area to determine its area in square millimeters $\left.\left(\mathrm{mm}^{2}\right) ; 2\right)$ digitalizing of images obtained on the vegetal paper for measuring using Image $]^{\circledR}$ software ${ }^{(24)}$, compared with the known area of a standard reference (Figure 1 ).

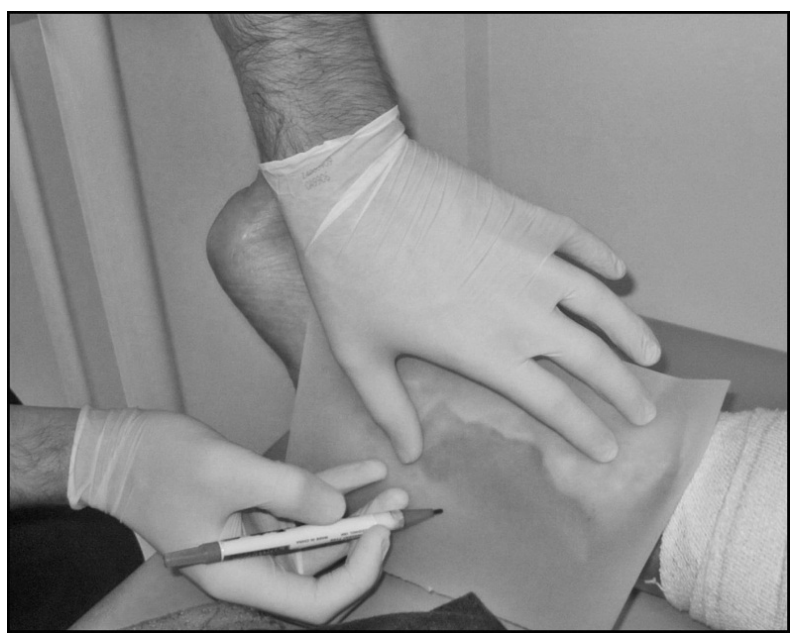

Figure1 - Delimitation of the ulcer area contours on vegetal paper

After the assessment, the subjects were randomly divided into the microcurrent group and the control group.

\section{Randomization}

In a convenience sample, the patients were randomized using random figures from a computer program. In this study, only the evaluator was blinded for the intervention performed.

\section{Application of the Microcurrent}

The microcurrent was applied using the equipment Neurodhyn Esthetic ${ }^{\circledR}$, brand IBRAMED, characterized by a monophasic rectangular pulse format, with polarity reversal every three seconds. The electric parameters used were: frequency of 5 Hertz and intensity of 500 microamperes $^{(17,25)}$. The bipolar technique was applied, using pen electrodes with a metal tip. The electrodes were placed on the external ulcer borders, on opposite sides, estimating one minute at each point. The entire ulcer border was contoured, with a one-centimeter distance between application points, returning to the initial point at the end of the application. To guarantee that the entire ulcer border would receive the stimulation, at the end of the application to the points, the application was extended for another minute, sliding the pen around the entire border. Hence, the application time was directly proportional to the ulcer area. The subjects received ten applications, three times per week, for four weeks (Figure 2).

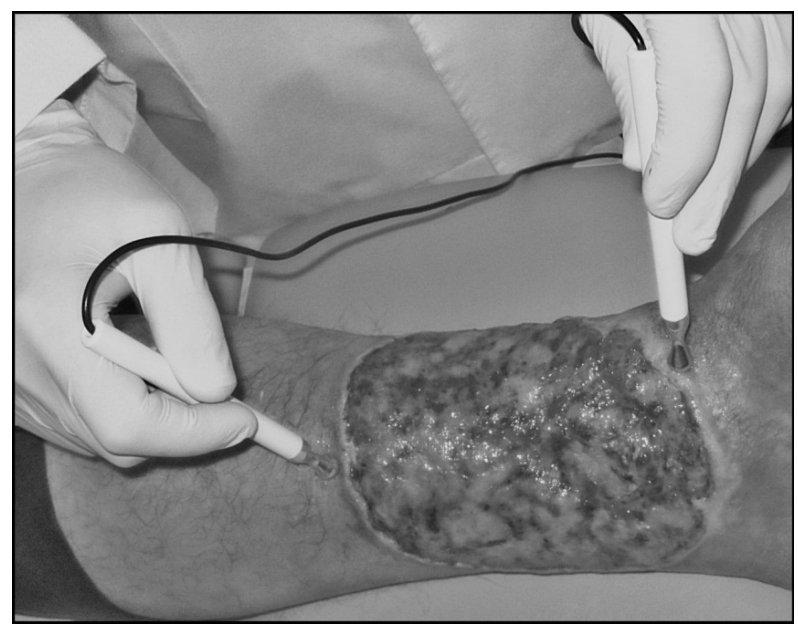

Figure 2 - Microcurrent application to the ulcer

The control group did not submit to any physiotherapeutic intervention, but maintained its clinical treatment routine based on simple dressings (general ulcer hygiene measures using saline solution and gauze occlusion) and lower limb degravitation.

Patients were assessed at the start of treatment (TO) and four weeks later (T4). The same evaluator, blinded to the interventions performed, collected all data. Statistical analysis was performed with the help of Statistical Package for the Social Sciences (SPSS) software, version 16.0 for Windows. All data were submitted to the Shapiro-Wilk test to check normality. Results were displayed as means and standard deviations, except for pain assessment results obtained with the help of the VAS (represented as medians and interquartile intervals). Intergroup differences were analyzed using Student's t-test for independent variables, the chi-square test and Mann-Whitney for non-parametric data.

\section{Results}

Twenty patients were assessed, 16 of whom were randomly distributed between the groups. Two patients 
included in the control group dropped out before the study started though, totaling a sample of 14 patients with a mean age of $62 \pm 9$ years (Figure 3 ). Intergroup differences were found for age only, as patients allocated to the microcurrent group were older than those allocated to the control group. Analyses for other demographic, socioeconomic and clinical characteristics demonstrated no significant difference between the groups (Table 1).

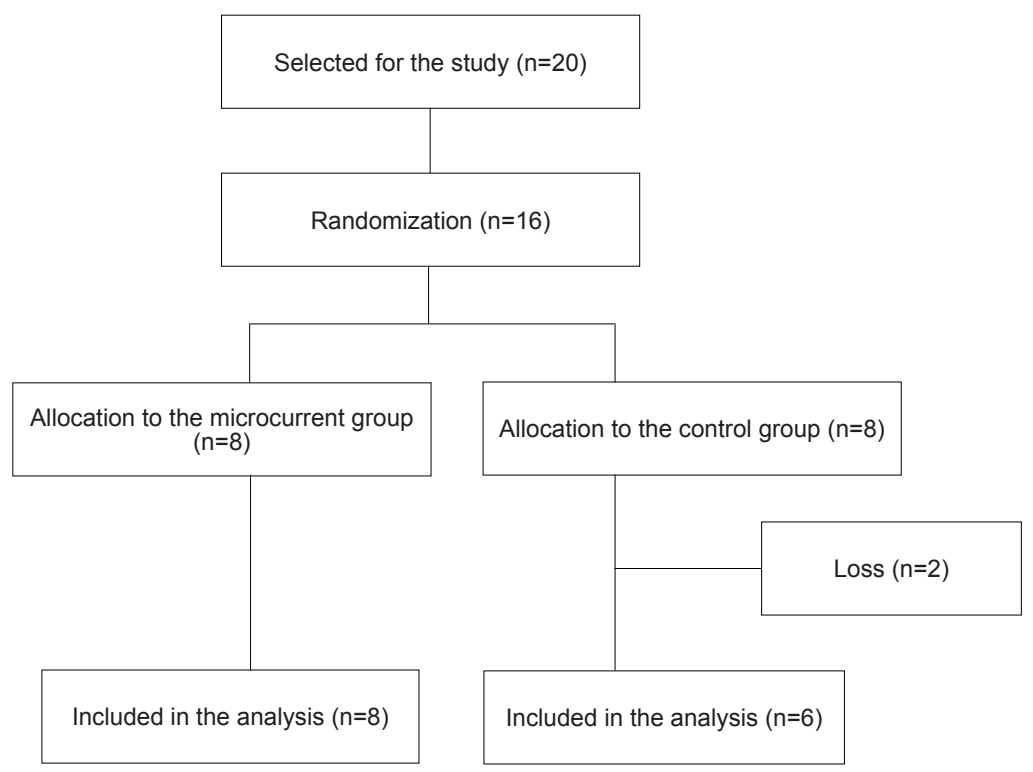

Figure 3 - Patient selection, randomization and analysis

Table 1 - Demographic, socioeconomic and clinical patient characteristics

\begin{tabular}{|c|c|c|c|}
\hline & Control group & Microcurrent group & \\
\hline & $N=6$ & $N=8$ & P \\
\hline Age (years, mean $\pm S D$ ) & $57 \pm 4,4$ & $67 \pm 10$ & $0,03^{*}$ \\
\hline \multicolumn{4}{|l|}{ Gender (n, \%) } \\
\hline Female & $4(66,6)$ & $3(37,5)$ & \multirow{2}{*}{0,08} \\
\hline Male & $2(33,3)$ & $5(62,5)$ & \\
\hline $\mathrm{BMI}\left(\mathrm{m} / \mathrm{Kg}^{2}\right.$, mean $\left.\pm \mathrm{SD}\right)$ & $26 \pm 3,6$ & $28,1 \pm 5,6$ & 0,10 \\
\hline Smoking (n, \%) & $5(83,3)$ & $5(62,5)$ & 0,41 \\
\hline Per capita income (mean \pm SD) & $420,6 \pm 83,7$ & $492,2 \pm 116,6$ & 0,63 \\
\hline Duration of ulceration (years, mean $\pm \mathrm{SD}$ ) & $8,0( \pm 9,4)$ & $12,8( \pm 10,5)$ & 0,74 \\
\hline Systemic arterial hypertension (n, \%) & $5(83,3)$ & $6(75,0)$ & 0,71 \\
\hline Walking difficulty $(\mathrm{n}, \%)$ & $5(83,3)$ & $5(62,5)$ & 0,71 \\
\hline \multicolumn{4}{|l|}{ Ulcer area $\left(\mathrm{mm}^{2}\right.$, mean $\left.\pm \mathrm{SD}\right)$} \\
\hline Vegetal paper & $7.591,3$ & $10.952,8$ & 0,57 \\
\hline Image J & $8.011,7$ & $10.839,6$ & 0,66 \\
\hline Pain (median, interquartile interval) & 7,5 & 8,5 & 0,75 \\
\hline
\end{tabular}

BMI: body mass index; * p-value $<0.05$

\section{Pain}

After four weeks of treatment, only patients allocated to the microcurrent group demonstrated a significant improvement between pain assessments pre and post-treatment, from 8.5 (6.5 - 9.75) to 3.5 (1 -
4.75), $\mathrm{p}<0.01$. Intergroup analysis showed a significant difference for the microcurrent group, $\mathrm{p}<0.01$ (Table 2).

\section{Ulcer area}

Concerning the ulcer area, after treatment, only the microcurrent group demonstrated a significant 
reduction, measured through the vegetal paper, from $10952.8 \pm 19585.3$ to $9352.1 \pm 17142.5, \mathrm{p}<0.01$ and also by applying Image $]^{\circledR}$ software, from $10839.6 \pm 18921.1$ to $9618.8 \pm 17015.0, \mathrm{p}<0.01$. Intergroup analysis demonstrated no significant difference for both assessment methods $(p=0.41)$ (Table 2$)$.

Table 2 - Patients' ulcer area and pain

\begin{tabular}{|c|c|c|c|c|c|c|}
\hline \multirow{3}{*}{ Lesion area } & \multicolumn{5}{|c|}{$\begin{array}{c}\text { Control group } \\
(n=6)\end{array}$} & \multirow{3}{*}{ P-value $^{\dagger}$} \\
\hline & \multicolumn{2}{|r|}{ Pre } & \multicolumn{2}{|r|}{ Post } & \multirow{2}{*}{ P-value* } & \\
\hline & $\mathrm{mm}^{2}$ & Mean \pm SD & $\mathrm{mm}^{2}$ & Mean \pm SD & & \\
\hline Vegetal paper & 7591.3 & \pm 6239.1 & 8175.7 & \pm 6308.6 & 0.17 & 0.41 \\
\hline \multirow[t]{2}{*}{ Image $\mathrm{J}^{\circledR}$} & 8011.7 & \pm 6346.7 & 8.600 .8 & \pm 6509.3 & 0.17 & 0.41 \\
\hline & Median & Interquartile interval & Median & Interquartile interval & P-value* & \\
\hline \multirow[t]{2}{*}{ Pain } & 7.5 & $5-75-10$ & 8.5 & $5.5-10$ & 0.56 & $<0.01 \S$ \\
\hline & \multicolumn{5}{|c|}{$\begin{array}{l}\text { Microcurrent group } \\
(n=8)\end{array}$} & \\
\hline \multirow[t]{2}{*}{ Lesion area } & \multicolumn{2}{|r|}{ Pre } & \multicolumn{2}{|r|}{ Post } & \multirow{2}{*}{ P-value ${ }^{\ddagger}$} & P-value ${ }^{\dagger}$ \\
\hline & $\mathrm{mm}^{2}$ & Mean \pm SD & $\mathrm{mm}^{2}$ & Mean \pm SD & & \\
\hline Vegetal paper & 10.952 .8 & \pm 19585.3 & 9352.1 & \pm 17142.5 & $<0.01^{\S}$ & 0.41 \\
\hline \multirow[t]{2}{*}{ Image $\mathrm{J}^{\circledR}$} & 10839.6 & \pm 18921.1 & 9618.8 & \pm 17015.0 & $<0.01^{\S}$ & 0.41 \\
\hline & Median & Interquartile interval & Median & Interquartile interval & P-value ${ }^{\ddagger}$ & \\
\hline Pain & 8.5 & $6.5-9.75$ & 3.5 & $1-4.75$ & $<0.01^{\S}$ & $<0.01^{\S}$ \\
\hline
\end{tabular}

* control pre $\mathrm{x}$ control post; ${ }^{\dagger}$ control $\mathrm{x}$ microcurrent; ${ }^{\ddagger}$ microcurrent pre $\mathrm{x}$ microcurrent post; ${ }^{\S} \mathrm{p}$ significant $<0,01$

\section{Discussion}

Chronic venous ulcers are determinants of worse socioeconomic conditions because they are reasons for absenteeism, which represent a burden for the health and social security system ${ }^{(3)}$, and because they establish a situation of functional dependence that puts a strain on family relations ${ }^{(26)}$. The rate of chronic injuries reveals the lack of problem-solving ability in the healing process of these wounds and the persistent influence of popular knowledge on personal care results in cases of intoxication or other health problems, due to the improper use of medicinal plants ${ }^{(3,26)}$. Therefore, actions need to be systemized with a view to patients' complete cure. In this respect, countless researchers have focused on the use of physical resources(27).

Among treatment resource options, this research focuses on the use of Microcurrent Electric Neuromuscular Stimulation - MENS, due to its results in pain control, edema control and wound healing, besides its anti-inflammatory and bactericide effects(22,28-29). Microcurrent electric stimulation applied to cutaneous injuries enhances tissue reparation because it normalizes the endogenous flow of the lesion currents (electric bioimpedance), which are situated in the same range as the microcurrent (in microamperes), expressing the idea that the microcurrent is defined as a physiological, homeostatic and normalizing electrostimulation ${ }^{(17,20,30-31)}$.
Nevertheless, although studies prove the benefic effects of the microcurrent in the pain and healing process of different tissues, little is known so far about its effects in venous ulcer treatment.

In this study, pain was assessed (VAS), as well as the ulcer area (planimetry) of individuals with venous ulcer. Concerning pain, the results demonstrated that the microcurrent effectively reduced the patients' pain after only four weeks of intervention. This result is important, as chronic ulcer compromise victims' quality of life, mainly due to the pain and loss of independence, besides the relation with the presence of local infection. Other studies support our results(20-22), demonstrating that the use of the microcurrent therapy for venous ulcers is promising and, as such, can offer a nonpharmacological approach to pain control, although the physiological mechanism has not been properly clarified yet.

What the quantification of ulcer size is concerned, using planimetry on vegetal paper and the software Image $]^{\circledR}$, these study results demonstrate a significant reduction in the ulcer area, after the applications, in the microcurrent group. When compared with the control group, however, the results were not significant, which can be justified by the short time during which the resource was applied and the limited sample size. As demonstrated in some studies, the application of microcurrent electric stimulation to cutaneous injuries 
enhances tissue reparation ${ }^{(20)}$ and produces an increase in protein synthesis, intracellular calcium levels, fibroblasts, adenosine triphosphate thymidine $e^{(28,30-31)}$. It also has bactericide effects and improves the formation and release of the vascular endothelial growth factor ${ }^{(22)}$.

In this study, groups were not homogeneous with regard to age only, as patients in the microcurrent group were older than in the control group. This fact did not represent a limitation though, as studies demonstrate that older individuals experience angiogenesis and blood vessel formation and, hence, healing difficulties(32-33), as well as larger ulcers with a longer duration of ulceration, entailing a worse cure prognosis, independently of the treatment ${ }^{(13)}$.

The period used to apply the microcurrent is considered a study limitation, with ten applications during an average period of 25 days, which is relatively short in comparison with other studies, which suggest 24 weeks as a reasonable period to identify the efficacy of chronic venous leg ulcer treatments. The results, however, indicate a trend to reduce the ulcer area size as the intervention time increases. It should be highlighted that, the shorter the treatment, the better the efficacy of the resource should be.

Another study limitation is the sample size, which reduces the study's power to identify intergroup differences. Nevertheless, the results demonstrated a significant improvement in the pain outcome and identified a clinical improvement for the injury size outcome.

Considering that the time to cure this disease and the presence of pain as a great complicating factor that significantly interferes in the victims' quality of life, studies that help to discover increasingly effective treatments are fundamental. In this perspective, this research adds value to the search for treatment alternatives for these patients.

Further research is needed to evidence the effectiveness of the microcurrent to accelerate the healing process. We suggest using other electric parameters, including intensity, application time and electrode positioning forms, as well as a larger number of application and longer follow-up time, with a view to the analysis of relapses.

With a view to understanding the healing of venous ulcers, it is important to associate techniques with the microcurrent, such as topical therapy or compressive methods, in line with international recommendations.

\section{Conclusion}

These study results demonstrated that microcurrent application permits reducing pain in venous ulcer patients.

\section{References}

1. Borges EL, Calin MHL, Hass VJ. Systematic review of topic treatment for venous ulcers. Rev. Latino-Am. Enfermagem. 2007;15(6):1163-70.

2. Azoubel R, Torres GV, Silva LWS, Gomes FV, Reis LA. Efeitos da terapia física descongestiva na cicatrização de úlceras venosas. Rev Esc Enferm USP. 2010;44(4):1085-92.

3. Abbade L, Lastoria S. Venous ulcer: epidemiology, physiopathology, diagnosis and treatment. Int J Dermatol. 2005;44:449-56.

4. Persoon A, MM, Van der Vleuten CJM, Rooi JMJ, Van De Kerkhof PCM, Van Achterberg T. Leg ulcers: a review of their impacto $n$ daily life. J Clin Nurs. 2004;13:341-54.

5. Green J, Jester R. Health-related quality of life and chronic venous leg ulceration: part 1 . Wound care. 2009; 12-7.

6. Mudge EJ, Meaume S, Woo K, Sibbald RG, Price PE. Patients experience of wound-related pain an international perspective. EWMA J. 2008;8(2):19-28.

7. Mc Mullen $M$. The relationship between pain and leg ulcers: a critical review. British Journal ao nursing. 2004;13(19):30-6.

8. Edwards $H$, Courtney $M$, Finlayson $K$, Shuter $P$, Lindsay $\mathrm{E}$. A randomised controlled trial of a community nursing intervention: improved quality of life and healing for clients with chronic leg ulcers. J Clin Nurs. 2009;18:1541-9.

9. Heinen MM, Van Achterberg T, Scholte Op Reimer W, Van De Kerkhof PCM, Laat E. Venous leg ulcer patients: a review of the literature on lifestyle and pain-related interventions. J Clin Nurs. 2004;13:355-66.

10. Hecke AV, Grypdonck M, Defloor T. A review of why patients with leg ulcers do not adhere to treatment. J Clin Nurs. 2009;18:337-49.

11. Brem H, Kirsner RS, Falanga V. Protocol for the sucessful treatment of venous ulcers. Am J Surgery. 2004;188 (Suppl):1-8

12. Herber OR, Schnepp W, Rieger MA. A systematic review on the impact of leg ulceration on patietns' quality of life. Health Qual Life Outcomes. 2007;5(44):1-12. 13. O'Meara S, Cullum N.A., Nelson E.A. Compression for venous leg ulcers. Cochrane Database of Systematic Reviews. The Cochrane Library. 2010;12. 
14. Palfreyman SJ, Nelson EA, Michaels JA. Apósitos para la cicatrización de las úlceras venosas de la pierna. Cochrane Database of Systematic Reviews. The Cochrane Library. 2010.

15. Whiddon LL. The treatment of venous ulcers of the lower extremities. Proc (Bay/Univ Med Cent). 2007;20(4):363-6.

16. Bevis P, Earnshaw J. Venous ulcer review. Clinical, Cosmetic and Investigational Dermatology. 2011;4:7-14.

17. Balakatounis KC, Angoules AG. Low-intensity electrical stimulation in wound healing: review of the efficacy of externally applied currents resembling the current of injury. J Plastic Surg. 2008;8:283-91.

18. Houghton PE, Kincaid $C B$, Lovell M, Campbell KE, Keast DH, Woodbury MG, et al. Effect of electrical stimulation on chronic leg ulcer size and appearance. Phys Ther. 2003;83(1):17-28.

19. Talebi G, Torkamma G, Firoozagadi M, Shariat S. Effect of anodal and cathodal microamperage direct current electrical stimulation on injury potential and wound size in guinea pigs. J Rehabil Res Develop. 2008;45(1):153-60.

20. Mercola JM, Kirsch DL. The basis for micro current electrical therapy in conventional medical practice. J Adv Med. 1995;8(2):83-152.

21. Ojingwa JC, Isseroff RR. Electrical stimulation of wound healing. J Invest Dermatol. 2003;121(1):1-12.

22. Ennis WJ, Lee C, Plumer M, Meneses P. Current status of the use of modalities in wound care: electrical stimulation and ultrasound therapy. Plastic Reconstruct Surg. 2011;127(1S):93-102.

23. Oien RF, Håkansson A, Hansen BU, Bjellerup M. Measuring the size of ulcers by planimetry: a useful method in the clinical setting. J Wound Care. 2002;11:165-8.

24. Miot HÁ, Mendaçolli TJ, Costa SV, Haddad GR, Abbade LPF. Úlceras crônicas dos membros inferiores: avaliação pela fotografia digital. Rev Assoc Méd Bras. 2009;55(2):145-8.

25. Asadi MR, Torkaman G, Hedayati M. Effect of sensory and motor electrical stimulation in vascular endothelial growth factor expression of muscle and skin in full-thickness wound. J Rehabil Res Develop. 2011;48(3):195-202.

26. Franks PJ, Moffatt CJ. Do clinical and social factors predict quality of life in leg ulceration? Int J Low Extrem Wounds. 2006;5:236-43.
27. Ferreira AS, Barbieri $\mathrm{CH}$, Mazzer $\mathrm{N}$, Campos $A D$, Mendonça AC. Mensuração de área de cicatrização por planimetria após aplicação do ultra-som de baixa intensidade em pele de rato. Rev Bras Fisiot. 2008;12(5):351-8.

28. Kloth LC. Electrical stimulation for wound healing: a review of evidence from in vitro studies, animal experiments, and clinical trials. Lower Extremity Wounds. 2005;4(1):23-44.

29. Cutting KF. Electric stimulation in the treatment of chronic wounds. Wounds UK. 2006;2(1):62-71.

30. Demir H, Balay H, Kirnap M. A comparative study of the effects of electrical stimulation and laser treatment on experimental wound healing in rats. J Rehabil Res Develop. 2004;41(2):147-54.

31. Lee BY, Stubbs D, Wendell K, Butler G, Al-Wall T, Al-Wall A. Ultra-low microcurrent in the management of diabetes mellitus, hypertension and chronic wounds: Report of twelve cases and discussion of mechanism of action. Int J Med Sci. 2010;7(1):29-35.

32. Chuanyoug LU, Hansen E, Sapazhnikova A, Diane HU, Miclau T, Marcucio RS. Effect of age on vascularization during fracture repair. J Orthop Res. 2008;26:1384-9.

33. Gist S, Tio Matos I, Falzgraf S, Cameron S, Beebe M. Wound care in the geriatric client. Dove press journal: Clin Interventions Aging. 2009;4:269-87. 